\title{
Effects of angiotensin II on insulin receptor binding and mRNA levels in normal and diabetic rats
}

\author{
L.A . Sechi ${ }^{1,2}$, C . A . G riffin ${ }^{2}$, L .Z ingaro ${ }^{1}$, J .-P.V alentin ${ }^{3}$, E . B artoli ${ }^{1}$, M . Schambelan ${ }^{2}$ \\ ${ }^{1}$ Hypertension Unit, Department of Internal Medicine, University of Udine, Udine, Italy \\ ${ }^{2}$ Division of Endocrinology and \\ ${ }^{3}$ Nephrology, San Francisco General Hospital, University of California San Francisco, San Francisco, California, USA
}

Summary Both the density and level of mRNA encoding insulin receptors in the kidney are inversely related to the dietary sodium content, suggesting a feedback mechanism that limits the insulin-induced sodium retention when extracellular fluid volume is expanded. Because angiotensin II affects tissue sensitivity to insulin in humans, we investigated whether angiotensin II affects insulin receptor binding and mRNA levels in the kidney, liver, and renal arteries of normal rats and rats with streptozotocin-induced diabetes mellitus. Non-diabetic and diabetic rats were infused for 7 days with either vehicle or angiotensin II at a rate of $200 \mathrm{ng} \cdot \mathrm{kg}^{-1} \cdot \mathrm{min}^{-1}$. In a separate experiment, normal rats were treated with an angiotensin converting enzyme inhibitor (captopril, $100 \mathrm{mg} / \mathrm{dl}$ in the drinking water) or vehicle for 7 days. Regional analysis of insulin receptor binding in the kidney and renal arteries was performed by an in situ technique using computerized microdensitometry and emulsion autoradiography. Insulin receptor mRNA levels were determined in renal and hepatic tissue by Northern blot hybridization and normalized with 28S rRNA. No differences in blood pressure were observed among diabetic and non-diabetic rats infused with either vehicle or angiotensin II, whereas captopril-treated rats had significantly lower blood pressure levels than their respective controls. Angiotensin II significantly decreased plasma renin concentration in both non-diabetic and diabetic rats. Insulin receptor number was significantly greater in the renal cortex of diabetic rats than in non-diabetics, whereas no significant differences were found in the outer medulla, inner medulla, or renal arteries. Angiotensin II infusion did not affect either the number or affinity of insulin receptors in any of the renal regions studied. Insulin receptor mRNA levels were significantly greater in the kidney and liver of diabetic rats than in non-diabetics and were not affected by angiotensin II infusion. Similar to angiotensin II infusion, captopril treatment did not affect either renal insulin receptor binding or mRNA levels. Thus, diabetic rats have increased insulin receptor binding and mRNA levels in comparison to non-diabetic rats. Angiotensin II infusion and captopril treatment do not affect insulin receptor binding and mRNA levels in the kidney, arguing against a role for this peptide in the modulation of renal sensitivity to insulin. [Diabetologia (1997) 40: 770-777]

Keywords Angiotensin II, autoradiography, captopril, insulin receptors, mRNA.
Received 14 November 1996 and in revised form: 4 March 1997

Corresponding author: L. A. Sechi, M. D., Department of Internal Medicine, University of Udine School of Medicine, Ospedale Civile, Padiglione Medicine, I-33100 Udine, Italy A bbreviations: STZ, Streptozotocin; ACE, angiotensin converting enzyme.
The observation that hyperinsulinaemia and insulin resistance are present in subjects with essential hypertension has led to the hypothesis that insulin is involved in the pathophysiology of this disease [1-3]. When considering possible pathogenetic mechanisms that could mediate the prohypertensive effect of insulin, particular attention has been paid to the renal actions of the hormone. Insulin decreases urinary sodium excretion in rats [4], dogs [5, 6], and humans [7, 
8], without affecting renal haemodynamics or glomerular filtration rate $[6,9]$. Recent experiments have shown that, in normal rats, there is an inverse relationship between dietary sodium intake and renal insulin receptor density and mRNA levels [10], suggesting the existence of a feedback mechanism that limits insulin-induced sodium retention when extracellular fluid volume is expanded. In addition to a direct effect of sodium in the kidney, changes in angiotensin II circulating levels, occurring as a consequence of changes in extracellular fluid volume, might be involved in the relationship between dietary salt and renal insulin receptors.

A possibile link between angiotensin II and insulin receptors is suggested also by recent studies performed in normal and diabetic humans in which it has been demonstrated that acute infusion of angiotensin II, administered in both pressor and subpressor doses, increases insulin sensitivity, as evaluated by measurement of glucose disposal rate during euglycaemic-hyperinsulinaemic clamp [11, 12]. Our aim in the present study was to investigate insulin receptor number and mRNA levels in tissues of rats studied under experimental conditions known to alter the activity of the renin-angiotensin system.

\section{Materials and methods}

A nimals. Male Sprague-Dawley rats (Bantin and Kingman, Fremont, Calif., USA) weighing 200-300 g, were housed in climate-controlled conditions $\left(70 \pm 5^{\circ} \mathrm{F}\right.$ and $55 \%$ relative humidity) with a 12 -h light-dark cycle (06.00 to 18.00 hours) and provided standard rat chow and water ad libitum. Diabetes $(n=20)$ was induced by intravenous administration of streptozotocin (STZ; Sigma Chemicals, St. Louis, Mo., USA), $60 \mathrm{mg} /$ $\mathrm{kg}$ body weight, dissolved in sodium citrate buffer $(0.1 \mathrm{mmol} / \mathrm{l}$, $\mathrm{pH} 4.5)$. Non-diabetic rats $(n=20)$, which were matched for age and weight, received an equal volume of the vehicle. Animals were considered to be diabetic if blood glucose levels were $20 \mathrm{mmol} / \mathrm{l}$ or more $72 \mathrm{~h}$ after the injection. Diabetic rats received a fixed dose (2 IU/day) of human recombinant insulin (Humulin U; Lilly, Indianapolis, Ind., USA) which was administered at 20.00 hours. Blood glucose levels were checked every other day by tail vein sampling (Accu-check bG; BioDinamics, Boehringer Mannheim, Indianapolis, Ind., USA). Ten days after administration of STZ or vehicle, rats were anaesthetized with sodium pentobarbital, $50 \mathrm{mg} / \mathrm{kg}$ i.p., and an osmotic minipump (model 2001; Alza, Palo Alto, Calif., USA) was implanted intraperitoneally. Ten rats from each subgroup received a pump containing angiotensin II (Human angiotensin II; Peninsula Laboratories, Belmont, Calif., USA) in a concentration designed to deliver at an infusion rate of $200 \mathrm{ng} \cdot \mathrm{kg}^{-1} \cdot \mathrm{min}^{-1}$, and the other 10 rats a pump containing the vehicle. One diabetic rat died during surgery. Angiotensin II was dissolved in saline containing bovine serum albumin $(48 \mathrm{mg} / \mathrm{ml})$ to avoid loss of peptide by adherence to the osmotic membrane. Rats were infused for 7 days. Systolic blood pressure was measured in conscious, prewarmed (light lamp), restrained rats by the tail-cuff method using plethysmography and a physiograph recorder (Pulse Amplifier; ITTC Life Science, Woodland Hills, Calif., USA). For these measurements, rats were trained before the study. Under such conditions, this indirect technique has been shown to be as reliable as direct arterial cannulation in both acute and chronic experiments $[13,14]$. At the end of the infusion periods, rats were fasted for $8 \mathrm{~h}$, killed by decapitation, and trunk blood was collected in 3K-EDTA and immediately chilled. Plasma was separated by centrifugation and stored at $-20^{\circ} \mathrm{C}$ for later determination of glucose, insulin, and renin concentrations. Kidneys were removed, weighed, and snap frozen in liquid nitrogen for both in situ insulin receptor assay and total RNA isolation. Liver was also removed and frozen for total RNA isolation.

In a separate experiment, rats received either captopril dissolved in the drinking water at a concentration of $100 \mathrm{mg} / \mathrm{dl}$ $(n=6)$, or vehicle $(n=6)$. After 7 days, rats were decapitated, and the kidneys handled as described above. In a separate group of captopril-treated rats $(n=6)$ and controls $(n=6)$ the efficacy of angiotensin-converting enzyme inhibition was assessed by determination of the pressor response to an i. v. bolus injection of $200 \mathrm{ng}$ of angiotensin I (Sigma Chemicals).

Plasma glucose, plasma insulin, and renin concentrations. Glucose was determined using a YSI model 23A glucose autoanalyser (Yellow Springs Instruments, Yellow Springs, Ohio, USA). Plasma insulin levels were determined by radioimmunoassay, using a double antibody technique [15]. Plasma renin concentration was determined as the rate of angiotensin I generation in plasma incubated for $2 \mathrm{~h}$ at $\mathrm{pH} 6.5$ in the presence of excess rat angiotensinogen using the method of Menard and Catt [16].

Insulin receptor binding studies. The distribution and binding characteristics of renal insulin receptors were assessed by an in situ autoradiographic technique associated with computerized microdensitometry, as previously described [10, 17]. Scatchard analysis of equilibrium binding data was obtained using the LIGAND program of Munson and Rodbard [18] and resulted in curvilinear profiles indicating either two classes of receptors (high-affinity, low-capacity and low-affinity, high-capacity), or the presence of a single class of receptors with a negative cooperative hormone-receptor interaction. In all the experiments data were analysed for a two-site model.

Vascular insulin receptor density was quantitated in the major branches of the renal artery by emulsion autoradiography [10] performed in $20 \mu \mathrm{m}$ thick renal tissue sections. The number of silver grains in five $0.083 \mathrm{~mm}^{2}$ squares within the artery wall was averaged after subtraction of the background number of grains from equivalent areas outside of the tissue perimeter on the same slide [19].

Insulin receptor mR NA studies. Total RNA was isolated from frozen tissue by a modification of the guanidine thiocyanate method of Chirgwin et al. [20] as described previously [10, 21]. Insulin receptor mRNA levels were quantitated by Northern blot hybridization analysis [10, 21, 22]. To assure equivalent loading conditions, duplicate blots were prepared and hybridized with a ${ }^{32} \mathrm{P}$-labelled oligonucleotide probe complementary to bases 4011-4036 of human 28S ribosomal RNA $[10,21]$.

Statistical analysis. Data are presented as means \pm SEM. Comparisons between groups were done by analysis of variance (Statview; Abacus, Berkeley, Calif., USA). Differences were considered to be statistically significant with a $p$ value less than 0.05 . 
Table 1. Plasma glucose, plasma insulin, body weight, kidney/ body weight ratio, systolic blood pressure, plasma renin concentration, and renal an hepatic $28 \mathrm{~S}$ ribosomal RNA levels in

\begin{tabular}{|c|c|c|c|c|c|c|c|c|c|}
\hline \multirow[t]{2}{*}{ Groups } & \multirow[t]{2}{*}{$\mathrm{n}$} & \multirow{2}{*}{$\begin{array}{l}\text { Plasma } \\
\text { glucose } \\
(\mathrm{mmol} / \mathrm{l})\end{array}$} & \multirow{2}{*}{$\begin{array}{l}\text { Plasma } \\
\text { insulin } \\
(\mathrm{pmol} / \mathrm{l})\end{array}$} & \multirow{2}{*}{$\begin{array}{l}\text { Body } \\
\text { weight } \\
(\mathrm{g})\end{array}$} & \multirow{2}{*}{$\begin{array}{l}\text { Kidney/body } \\
\text { ratio }(\times 1000)\end{array}$} & \multirow{2}{*}{$\begin{array}{l}\text { Blood } \\
\text { pressure } \\
(\mathrm{mm} \mathrm{Hg})\end{array}$} & \multirow{2}{*}{$\begin{array}{l}\text { Plasma renin } \\
\text { concentration } \\
\left(\mathrm{ng} \cdot \mathrm{l}^{-1} \cdot \mathrm{s}^{-1}\right)\end{array}$} & \multicolumn{2}{|l|}{ 28S rRNA } \\
\hline & & & & & & & & kidney & liver \\
\hline Non-diabetic+ & 10 & $7.3 \pm 0.2$ & $7.9 \pm 0.5$ & $286 \pm 7$ & $7.31 \pm 0.16$ & $142 \pm 3$ & $4.6 \pm 1.8$ & 12.1 & 14.9 \\
\hline Diabetic+vehicle & 9 & $27.4 \pm 2.2^{\mathrm{b}}$ & $3.1 \pm 0.7^{b}$ & $236 \pm 4^{b}$ & $9.84 \pm 0.32^{b}$ & $144 \pm 2$ & $5.9 \pm 2.0$ & $12.7 \pm 1.2$ & $15.6 \pm 1.7$ \\
\hline Diabetic+ANG II & 10 & $28.5 \pm 1.5^{\mathrm{b}}$ & $3.8 \pm 0.5^{\mathrm{b}}$ & $230 \pm 4^{\mathrm{b}}$ & $10.25 \pm 0.23^{\mathrm{a}, \mathrm{b}}$ & $145 \pm 3$ & $0.6 \pm 0.3^{\mathrm{a}}$ & $12.4 \pm 1.7$ & $14.4 \pm 2.2$ \\
\hline
\end{tabular}

Data are means \pm SEM of the values obtained 14 days after intravenous administration of STZ $(60 \mathrm{mg} / \mathrm{kg})$ or vehicle and 7 days after intraperitoneal infusion of angiotensin II (ANG II) $\left(200 \mathrm{ng} \cdot \mathrm{kg}^{-1} \cdot \mathrm{min}^{-1}\right)$ or vehicle. Diabetic rats received a low dose of insulin (2 IU/day) to maintain a moderate hyperglycaemic state. Plasma glucose, plasma insulin, and plasma renin non-diabetic and STZ-diabetic rats infused with either vehicle or angiotensin II

concentration were measured on trunk blood obtained at the time of killing. Plasma insulin and plasma renin concentration were measured in 5 rats in each group. RNA data are expressed in arbitrary scanner units (SU). Intergroup comparisons were done by ANOVA. ${ }^{a} p<0.05$ vs non-diabetics infused with vehicle; ${ }^{b} p<0.001$ vs respective or diabetic controls

Table 2. Body weight, kidney/body weight ratio, systolic blood pressure, plasma renin concentration, and blood pressure response to intravenous administration of angiotensin I in captopril-treated and control rats

\begin{tabular}{|c|c|c|c|c|c|c|c|}
\hline Groups & $\mathrm{n}$ & $\begin{array}{l}\text { Body weight } \\
\text { (g) }\end{array}$ & $\begin{array}{l}\text { Kidney/body } \\
\text { ratio }(\times 1000)\end{array}$ & $\begin{array}{l}\text { Blood pressure } \\
(\mathrm{mm} \mathrm{Hg})\end{array}$ & $\begin{array}{l}\text { Plasma renin concen- } \\
\text { tration }\left(\mathrm{ng} \cdot \mathrm{l}^{-1} \cdot \mathrm{s}^{-1}\right)\end{array}$ & $\begin{array}{l}\Delta \text { Blood pressure } \\
(\mathrm{mm} \mathrm{Hg})\end{array}$ & $\begin{array}{l}\text { 28S rRNA } \\
\text { kidney }\end{array}$ \\
\hline Control & 6 & $348 \pm 8$ & $7.42 \pm 0.08$ & $143 \pm 4$ & $3.9 \pm 1.4$ & $42 \pm 4$ & $10.7 \pm 3.2$ \\
\hline Captopril & 6 & $345 \pm 5$ & $7.36 \pm 0.05$ & $133 \pm 2^{b}$ & $16.5 \pm 6.4^{\mathrm{a}}$ & $4 \pm 1^{b}$ & $11.2 \pm 2.7$ \\
\hline
\end{tabular}

Data are means \pm SEM of the values obtained in captopriltreated $(100 \mathrm{mg} / \mathrm{dl}$ in the drinking water, for 7 days $)$ and control rats. Plasma renin concentration was measured on trunk blood obtained at the time of killing. The efficacy of angiotensin-converting enzyme inhibition was assessed by determi- nation of the pressor response to an i.v. bolus injection of $200 \mathrm{ng}$ of angiotensin I ( $\Delta$ Systolic blood pressure). RNA data ar expressed in arbitrary scanner units (SU). Intergroup comparisons were done by ANOVA. ${ }^{a} p<0.05$ vs control; ${ }^{\mathrm{b}} \mathrm{p}<0.01$ vs control

Table 3. Insulin binding characteristics in kidneys of non-diabetic and STZ-diabetic rats infused with either vehicle or angiotensin II, and in captopril-treated and control rats

\begin{tabular}{|c|c|c|c|c|c|}
\hline \multirow[t]{2}{*}{ Groups } & \multirow[t]{2}{*}{$\mathrm{n}$} & \multicolumn{2}{|l|}{$\mathrm{R} 1$} & \multicolumn{2}{|l|}{$\mathrm{R} 2$} \\
\hline & & $\begin{array}{l}\mathrm{K}_{\mathrm{d}} \\
\times 10^{-10} \mathrm{~mol}\end{array}$ & $\begin{array}{l}\mathrm{B}_{\max } \\
\times 10^{10} \text { receptors } / \mathrm{mm}^{3}\end{array}$ & $\begin{array}{l}\mathrm{K}_{\mathrm{d}} \\
\times 10^{-7} \mathrm{~mol}\end{array}$ & $\begin{array}{l}\mathrm{B}_{\max } \\
\times 10^{13} \text { receptors } / \mathrm{mm}^{3}\end{array}$ \\
\hline Non-diabetic+ANG II & 6 & $3.9 \pm 1.4$ & $6.7 \pm 0.7$ & $2.6 \pm 1.4$ & $8.2 \pm 2.0$ \\
\hline Diabetic+vehicle & 6 & $3.7 \pm 0.9$ & $8.4 \pm 1.1^{\mathrm{a}}$ & $3.1 \pm 1.8$ & $7.8 \pm 1.7$ \\
\hline Diabetic+ANG II & 6 & $4.0 \pm 1.0$ & $8.2 \pm 1.7^{\mathrm{a}}$ & $3.3 \pm 1.3$ & $8.0 \pm 1.9$ \\
\hline
\end{tabular}

Values are means \pm SEM. Binding parameters were derived from Scatchard analysis of equilibrium binding data from competition experiments performed on adjacent kidney sections. $\mathrm{R} 1$, high-affinity, low-capacity insulin binding site. R2, low-af-

\section{Results}

Plasma glucose, plasma insulin, body and kidney weight, blood pressure, and plasma renin concentration (Table 1 and Table 2). Plasma glucose increased promptly after administration of STZ and remained significantly higher than control in diabetic rats that received low-dose (2 IU/day) insulin therapy. Plasma insulin levels and body weight were significantly lower in diabetic rats as compared to non-diabetics. Chronic angiotensin II infusion did not affect plasma glucose, plasma insulin and body weight in either diabetic or non-diabetic rats. The kidney weight/body finity, high-capacity insulin binding site. $\mathrm{K}_{\mathrm{d}}$, apparent dissociation constant. $\mathrm{B}_{\max }$, maximum binding capacity. ${ }^{\mathrm{a}} \mathrm{p}<0.05$ vs respective control

weight ratio was significantly greater in diabetic than non-diabetic rats and was significantly increased by angiotensin II infusion in diabetic rats. Plasma renin concentration was comparable in non-diabetic and diabetic rats and was reduced significantly by angiotensin II in both groups, indicating effective suppression of the circulating renin-angiotensin system. Systolic blood pressure was comparable in diabetic and control rats and was not affected significantly by angiotensin II infusion.

Captopril treatment decreased blood pressure, increased plasma renin concentration and did not affect body and kidney growth. Captopril treatment 
Insulin Binding
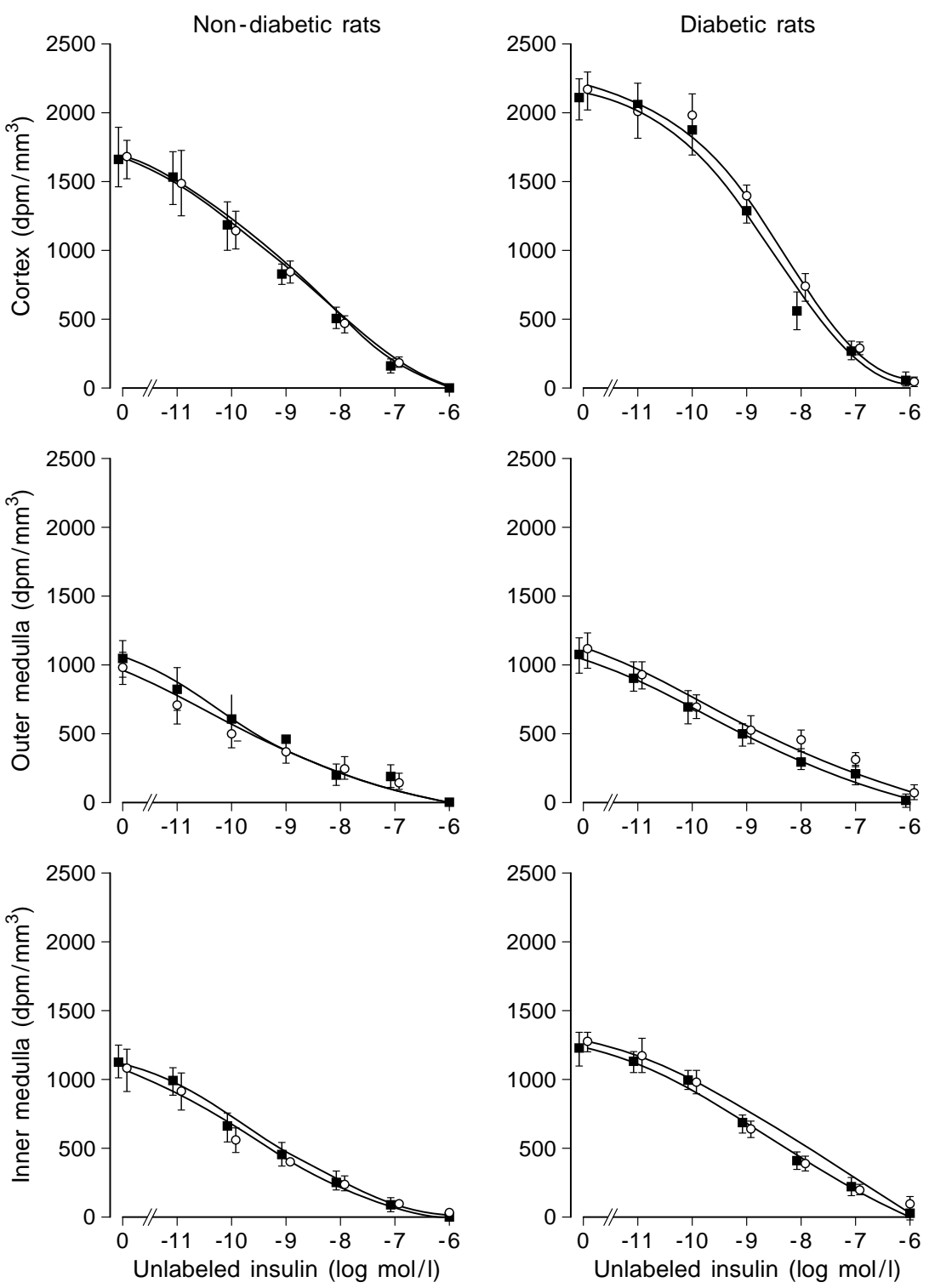

Fig. 1. Effect of varying concentrations of unlabelled insulin on binding of ${ }^{125} \mathrm{I}$-insulin in cortex, outer medulla, and inner medulla of kidneys obtained from non-diabetic and STZ-diabetic rats after intraperitoneal infusion of angiotensin II $\left(200 \mathrm{ng} \cdot \mathrm{kg}^{-1} \cdot \min ^{-1}\right)(\boldsymbol{\square})$ or vehicle $(\mathrm{O})$ for 7 days. Data were obtained by computerized microdensitometry and are means \pm SEM of 6 animals in each group. For each rat the area below the curve was calculated and the average of the groups compared by analysis of variance. Insulin receptor density was significantly greater in the renal cortex of diabetic rats infused with either angiotensin II or vehicle vs the respective control group $(p<0.02$ for both angiotensin II and vehicle infused rats)

markedly reduced the pressor response to a bolus injection of angiotensin I, indicating effective suppression of the angiotensin-converting enzyme.

Insulin receptor binding. In all the groups radioligand binding was more abundant in renal cortex than

medulla. In the cortex, binding intensity was comparable in glomeruli and tubules. The distribution of binding in different kidney regions was comparable in diabetic and non-diabetic rats (Fig. 1). Non-specific binding was less than $10 \%$ in all of the groups. Binding data, analysed for a two-site model, showed a greater number of the high-affinity, low-capacity insulin receptor sites in kidneys of diabetic rats as compared to non-diabetics (Table 3). No significant differences were observed in the maximum binding capacity $\left(\mathrm{B}_{\max }\right)$ of the low-affinity, high-capacity site and in the apparent dissociation constant $\left(\mathrm{K}_{\mathrm{d}}\right)$ of both high-affinity and low-affinity receptor sites (Table 3). Insulin receptor number was significantly greater in the renal cortex of diabetic rats than in non-diabetics, whereas no significant differences were found in the outer or the inner medulla (Fig. 1). In both diabetic and non-diabetic rats, chronic angiotensin II infusion did not affect $\mathrm{B}_{\max }$ or $\mathrm{K}_{\mathrm{d}}$ of either 

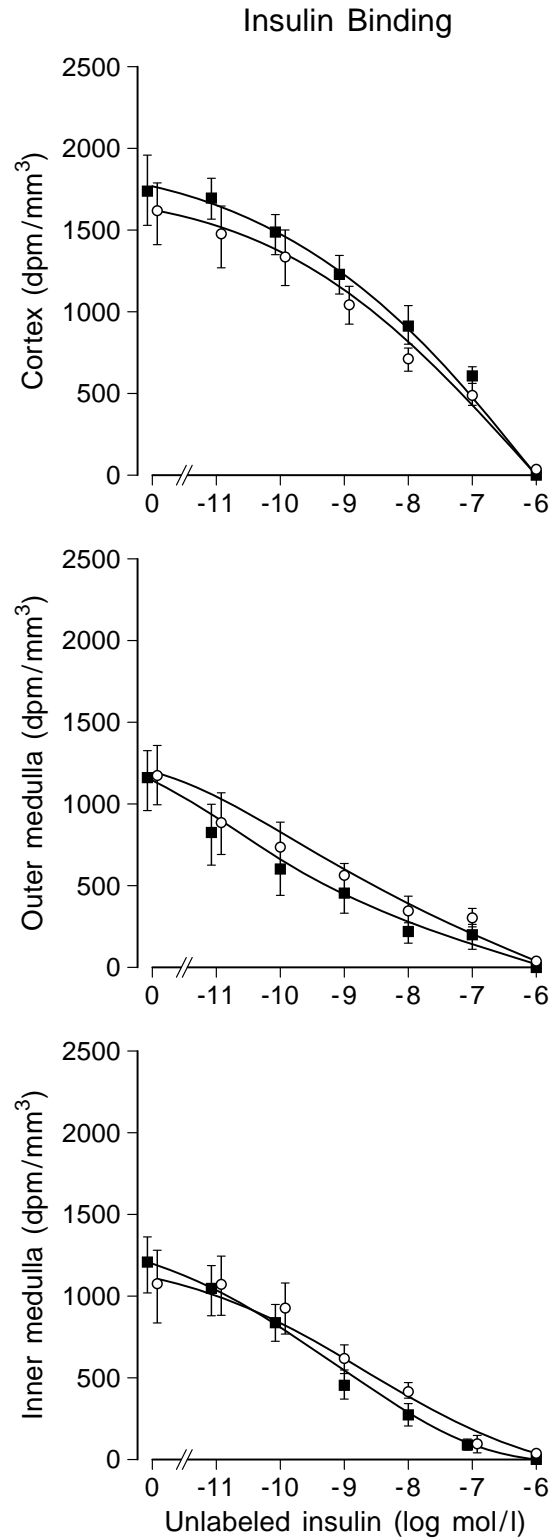

Fig. 2. Effect of varying concentrations of unlabelled insulin on binding of ${ }^{125} \mathrm{I}$-insulin in cortex, outer medulla, and inner medulla of kidneys obtained from captopril-treated $(\boldsymbol{v})$ and control ( $\bigcirc$ ) rats. Data were obtained by computerized microdensitometry and are means \pm SEM of 6 animals in each group. For each rat the area below the curve was calculated and the average of the groups compared by analysis of variance. Insulin receptor density did not differ between the groups in any of the regions analysed

insulin binding sites in any of the regions analysed (Fig. 1 and Table 3). Similar to angiotensin II infusion, captopril treatment did not affect either the distribution of insulin receptors nor the binding parameters of both receptor sites in any of the regions analysed (Fig. 2 and Table 3).

Vascular insulin receptor density, as measured by emulsion autoradiography of renal arteries, was comparable in diabetic and non-diabetic rats infused with either vehicle or angiotensin II (Table 4). Similarly,
Table 4. Insulin receptor density in renal arteries of non-diabetic and STZ-diabetic rats infused with either vehicle or angiotensin II, and in captopril-treated and control rats

\begin{tabular}{lll}
\hline Groups & $\mathrm{n}$ & silver grains $/ \mathrm{mm}^{2}$ \\
\hline Non-diabetic+vehicle & 5 & $1226 \pm 129$ \\
Non-diabetic+ANG II & 5 & $1122 \pm 103$ \\
Diabetic+vehicle & 5 & $1130 \pm 182$ \\
Diabetic+ANG II & 5 & $1189 \pm 141$ \\
Control & 6 & $1437 \pm 228$ \\
Captopril & 6 & $1261 \pm 202$
\end{tabular}

Values are means \pm SEM. Vascular insulin receptor abundance was quantitated by emulsion autoradiography performed on $20 \mu \mathrm{m}$ thick renal sections. Two tissue sections from each animal were evaluated. The number of silver grains in five $0.083 \mathrm{~mm}^{2}$ squares within the wall of the major branches of the renal artery was counted and averaged after the subtraction of the background number of grains from equivalent areas outside of the tissue perimeter on the same slide

captopril treatment did not affect insulin receptor abundance in renal arteries (Table 4).

Insulin receptor mRNA studies. Northern blot analysis of insulin receptor mRNA in kidney revealed greater levels in diabetic rats in comparison to nondiabetics. In both diabetic and non-diabetic rats, renal insulin receptor mRNA levels were not significantly different in those that had been infused with angiotensin II in comparison to those infused with vehicle (Fig. 3 and Fig. 4). Similar to the kidney, insulin receptor mRNA levels in liver were significantly greater in diabetic than non-diabetic rats (Fig.3). Angiotensin II infusion did not have any significant effect on this tissue either. Levels of $28 \mathrm{~S}$ ribosomal RNA were comparable in kidney and liver tissue of non-diabetic and diabetic rats infused with both angiotensin II and vehicle (Table 1). Renal mRNA levels were comparable in kidney tissue of the captopril-treated $(5.6 \pm 0.1$ scanner units; $n=6)$ and control $(5.5 \pm 0.2$ scanner units; $n=6$ ) rats.

\section{Discussion}

The results of the present study demonstrate that renal insulin receptor number and renal and hepatic mRNA levels are increased in STZ-diabetic rats in comparison to controls. Neither chronic angiotensin II infusion, in doses sufficient to inhibit the circulating renin-angiotensin system, nor captopril treatment, in doses sufficient to block the pressor response to i. v. administration of angiotensin I, affected either insulin receptor binding or tissue mRNA levels.

Significant differences in insulin binding and insulin receptor mRNA levels between insulinopenic and control rats have been noted in previous studies. In both liver and kidney, insulin receptor number [23-26] and mRNA levels [21] are inversely related 

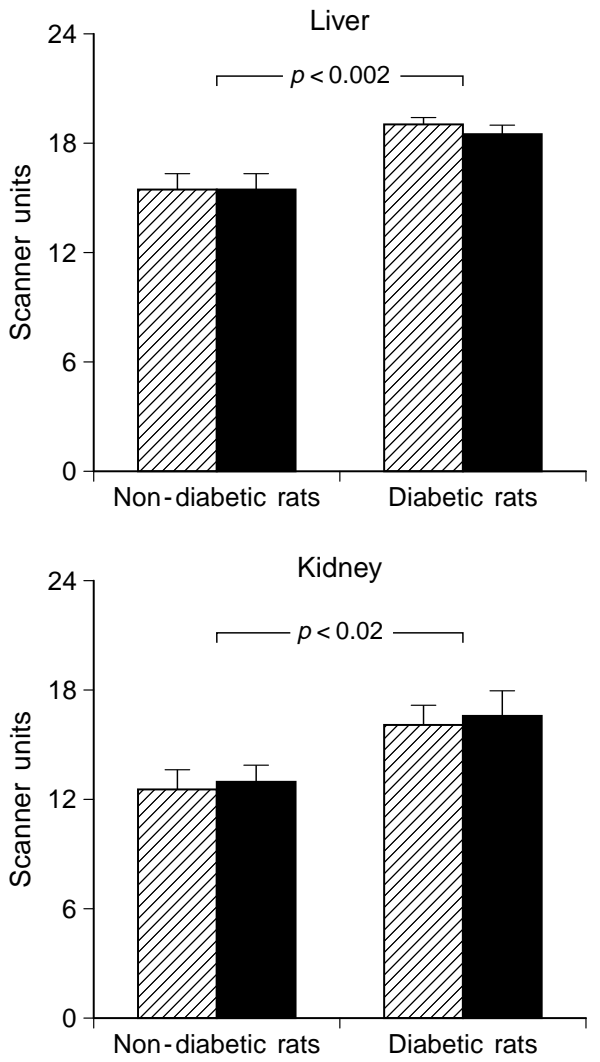

Fig. 3. Insulin receptor mRNA in liver (upper panel) and kidney (lower panel) of non-diabetic and STZ-diabetic rats after intraperitoneal infusion of angiotensin II $\mathbf{~ ( 2 0 0 ~ n g ~ . ~}$ $\left.\mathrm{kg}^{-1} \cdot \min ^{-1}\right)$ or vehicle $\mathbb{Z}$ for 7 days. Data are the means \pm SEM of 10 animals in each group. The groups were compared by analysis of variance

to the plasma insulin level, whereas in other tissues, such as brain [21, 27, 28], this does not occur. Homologous insulin receptor up-regulation, as a result of decreased ambient insulin concentration, is the likely mechanism accounting for increased insulin receptor number in liver and kidney. This is confirmed by experiments performed in cultured cells [29, 30]. With regard to the kidney, the present study demonstrates that insulin receptors are up-regulated in the renal cortex of insulin-deficient rats.

At physiological concentrations, insulin increases sodium reabsorption in the isolated perfused kidney [6] without affecting renal haemodynamics or glomerular filtration rate. The exact site of tubular action of insulin is still unclear. Previous reports have indicated an effect of the hormone in the proximal tubule [31], distal tubule [5], and the loop of Henle [32]. Evidence for a sodium-retaining effect of insulin also comes from clinical studies in which increased sodium excretion associated with normalization of blood pressure has been observed in non-insulin-dependent diabetic hypertensive subjects after the reduction of insulin dosage [8]. This and other observations have led investigators to hypothesize a role for insulin in the pathophysiology of arterial hypertension [1-3]. In a recent study, we have found that the number of insulin receptors in normal rat kidney is down-regulated by high sodium chloride intake and this effect is mediated by changes of insulin receptor mRNA levels [10]. Because regulation of receptor number is a mechanism that serves to modify the response of the cell to circulating insulin, our findings are consistent with the existence of a feedback mechanism that could reduce insulin-induced sodium retention when extracellular fluid volume is expanded. The effect of salt on insulin receptors might be mediated by a direct renal action or, alternatively, by changes in factors involved in the regulation of water and electrolyte homeostasis. One of the aims of the present study was to test the hypothesis that the relationship between dietary salt and renal insulin receptors is mediated by changes in the circulating levels of angiotensin II. In both control and STZ-diabetic rats, chronic infusion of angiotensin II induced suppression of plasma renin concentration and renal hypertrophy, but no change was observed in renal insulin receptor number and mRNA levels. In addition, chronic captopril treatment blocked the pressor response to i.v. angiotensin I, but did not affect insulin receptor number and mRNA levels in the kidney. This observation suggests that angiotensin II has no role in sodiumdependent insulin receptor regulation and is consistent with the findings of a recent study performed in normal men, in which it has been demonstrated that the antinatriuretic action of insulin is unchanged after chronic blockade of angiotensin I converting enzyme [33].

Recent studies have investigated the effects of acute angiotensin II infusion on insulin sensitivity in humans by measurement of the rate of disposal of glucose during a euglycaemic-hyperinsulinaemic clamp. Morris et al. [34] and Townsend et al. [35] did not observe changes in the rate of glucose disposal in healthy subjects during infusion of low-dose angiotensin II (5 and $10 \mathrm{ng} \cdot \mathrm{kg}^{-1} \cdot \mathrm{min}^{-1}$ ). Subsequently, the same authors, using higher doses of angiotensin II $\left(15 \mathrm{ng} \cdot \mathrm{kg}^{-1} \cdot \min ^{-1}\right)$, found that this peptide increases the rate of glucose disposal and therefore insulin sensitivity both in healthy [11] and non-insulin-dependent diabetic subjects [12]. In another study, a dose-dependent relationship between angiotensin II and insulin sensitivity was demonstrated over a wide range of peptide doses (from 2 to $20 \mathrm{ng} \cdot \mathrm{kg}^{-1} \cdot \mathrm{min}^{-1}$ ), an effect that was attributed to redistribution of blood flow from the splanchnic and visceral circulation toward skeletal muscle [36]. Other studies conducted in both healthy [37] and diabetic subjects [12], however, suggested that the haemodynamic effect of angiotensin II might not be the sole underlying mechanism. This implies that angiotensin II may affect insulin action also at the 

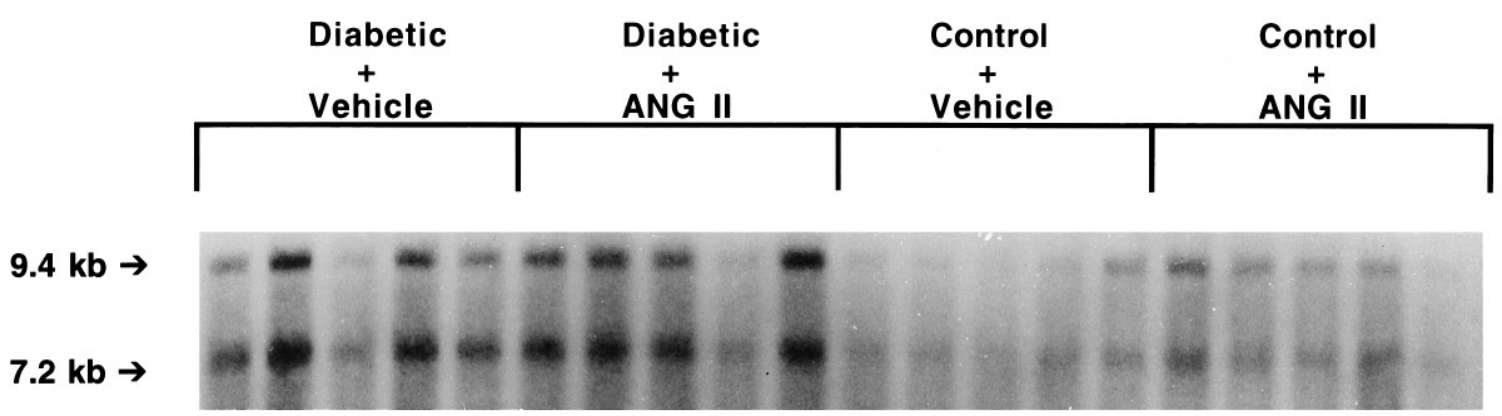

28S

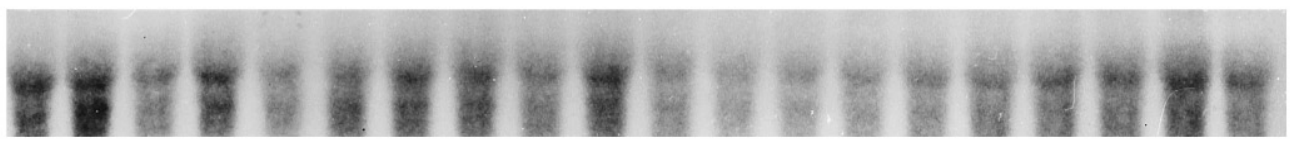

Fig. 4. Representative Northern blot of insulin receptor mRNA in kidney of non-diabetic and STZ-diabetic rats after intraperitoneal infusion of angiotensin II $\left(200 \mathrm{ng} \cdot \mathrm{kg}^{-1} \cdot \mathrm{min}^{-1}\right)$ or vehicle for 7 days. The hybridization reaction was performed employing an antisense $\left[{ }^{32} \mathrm{P}\right]$-labelled riboprobe. Two major bands characteristic of rat insulin receptor mRNA were seen at 7.2 and 9.4 kilobases. Both transcripts were significantly higher in diabetic rats as compared to non-diabetic controls. In both diabetic and non-diabetic rats, renal insulin receptor mRNA levels were not significantly different in those that had been infused with angiotensin II in comparison to those infused with vehicle

cellular level through a direct biochemical effect. In the present study, no effects of chronic angiotensin II infusion were noted on hepatic, renal, and vascular insulin receptors in non-diabetic and diabetic rats. Although insulin binding was not measured in the liver, it is known that there is a very good correlation between the levels of insulin receptor mRNA and the number of receptors [38]. Although comparison with previous studies is difficult because of important differences in the experimental models, the present study suggests that angiotensin II does not affect insulin sensitivity through changes in insulin receptor number. The findings of the present study do not rule out the possibility that angiotensin II modulates the effects of insulin at a post-receptor step. To suggest this possibility, a recent study by Velloso et al. [39] has demonstrated a cross-talk between the insulin and angiotensin signalling systems in cardiac tissue obtained from anaesthetized rats.

There is evidence that administration of angiotensin converting enzyme (ACE) inhibitors, which presumably reduce plasma levels of angiotensin II, may enhance insulin sensitivity in both non-diabetic and diabetic subjects [40-42]. This observation appears to be in conflict with the findings of increased insulin sensitivity during acute angiotensin infusion $[11,12,36,37]$. A possible explanation is that the facilitatory effects of ACE inhibitors on glucose disposal might be related to accumulation of kinins [43] instead of reduction of angiotensin II levels.

In the present study we have not observed significant differences in blood pressure, as measured by the tail-cuff method, between diabetic and non-diabetic rats. Other studies have investigated the blood pressure effect of insulin-dependent diabetes by use of the STZ-diabetic rat model and the results of these studies are conflicting inasmuch as increased [44-46], unchanged [47, 48], and even decreased [49] levels have been reported in diabetics as compared to controls. Although technical problems related to the tailcuff method have been proposed as a possible explanation [44], these discrepancies are independent of the method of measurement of blood pressure and appear to be most likely related to differences in the age of rats, severity and duration of diabetes, presence of overt diabetic nephropathy, or dietary salt content.

In summary, diabetic rats have increased insulin receptor binding and $\mathrm{mRNA}$ levels in comparison to control rats. Chronic angiotensin II infusion and captopril treatment do not affect insulin receptor binding and mRNA levels in the kidney, arguing against a role for angiotensin II in the modulation of renal sensitivity to insulin.

A cknowledgements. This research was supported by U.S. Public Health Research Grant (HL-11046) from the National Heart, Lung, and Blood Institute and C. N. R. (Consiglio Nazionale delle Ricerche, 92.01096.CT04 and 94.084231.CT04) Grants. L. A. Sechi was the recipient of a Fulbright Award and a Ferrero Foundation Grant.

\section{References}

1. Ferrannini E, Buzzigoli G, Bonadonna R, et al. (1987) Insulin resistance in essential hypertension. N Engl J Med 317: 350-357

2. Sechi LA, Melis A, Tedde R (1992) Insulin hypersecretion: a distinctive feature between essential and secondary hypertension. Metabolism (Clinical and Experimental) 41: 1261-1266

3. Ferrari P, Weidmann P (1990) Insulin, insulin sensitivity and hypertension. J Hypertens 8: 491-500 
4. Finch D, Davis G, Bower J, Kirchner K (1990) Effect of insulin on renal sodium handling in hypertensive rats. Hypertension 15: 514-518

5. De Fronzo RA, Goldberg M, Agus Z (1976) The effects of glucose and insulin on renal electrolyte transport. J Clin Invest 58: 83-90

6. Nizet A, Lefebvre P, Crabbe J Control by insulin of sodium, potassium, and water excretion by the isolated dog kidney. Pflueg Arch 323: 11-20

7. De Fronzo RA, Cooke CR, Andres R, Faloona GR, Davis PJ (1975) The effect of insulin on renal handling of sodium, potassium, calcium, and phosphate in man. J Clin Invest 55: 845-855

8. Tedde R, Sechi LA, Marigliano A, Pala A, Scano L (1989) Antihypertensive effect of insulin reduction in diabetic-hypertensive patients. Am J Hypertens 2: 163-170

9. Sechi LA, Marigliano A, Tedde R (1991) Evaluation of insulininduced changes in the renal response to furosemide in normal subjects. Miner Electrolyte Metab 17: 383-389

10. Sechi LA, Griffin CA, Schambelan M (1994) Effect of dietary sodium chloride on insulin receptor number and mRNA levels in the kidney of the rat. Am J Physiol 266 (Renal Fluid Electrolyte Physiol. 24) 266: F31-F38

11. Townsend RR, DiPette DJ (1993) Pressor doses of angiotensin II increase insulin-mediated glucose uptake in normotensive men. Am J Physiol 265 (Endocrinol. Metab. 28): E362-E366

12. Morris AD, Petrie JR, Ueda S et al. (1994) Pressor and subpressor doses of angiotensin II increase insulin sensitivity in NIDDM. Diabetes 43: 1445-1449

13. Bunag RD, Butterfield J (1982) Tail-cuff blood pressure measurement without external preheating in awake rats. Hypertension 4: 898-903

14. Sechi LA, Palomba D, Bartoli E (1993) Acute effects of furosemide on blood pressure in functionally anephric, volume-expanded rats. Am J Nephrol 13: 94-99

15. Feingold KR, Soued M, Staprans I, et al. (1989) Effect of tumor necrosis factor (TNF) on lipid metabolism in the diabetic rat: evidence that inhibition of adipose tissue lipoprotein lipase activity is not required for TNF-induced hyperlipidemia. J Clin Invest 83: 1116-1121

16. Menard J, Catt KJ (1972) Measurement of renin activity, concentration and substrate in rat plasma by radioimmunoassay of angiotensin I. Endocrinology 90: 422-430

17. Sechi LA, De Carli S, Bartoli E (1994) In situ characterization of renal insulin receptors in the rat. J Receptor Res 14: 347-356

18. Munson PJ, Rodbard D (1980) Ligand: a versatile computerized approach for characterization of ligand-binding system. Anal Biochem 107: 220-239

19. Kalinyak JE, Sechi LA, Griffin CA et al. (1993) The renin-angiotensin system in streptozotocin-induced diabetes mellitus in the rat. J Am Soc Nephrol 4: 1337-1345

20. Chirgwin JM, Przybyla AE, McDonald RJ, Rutter WJ (1979) Isolation of biologically active ribonucleic acid from sources enriched in ribonuclease. Biochemistry 18: 5294-5299

21. Sechi LA, Griffin CA, Grady EF, Kalinyak JE, Schambelan M (1992) Tissue-specific regulation of insulin-receptor mRNA levels in rats with streptozocin-induced diabetes. Diabetes 41: $1113-1118$

22. Goldstein BJ, Dudley AL (1990) The rat insulin receptor: primary structure and conservation of tissue-specific alternative messenger RNA splicing. Mol Endocrinol 4: 235-244

23. Davidson MB, Solomon AK (1977) Increased insulin binding by hepatic plasma membranes from diabetic rats. J Clin Invest 59: 22-30

24. Kadowaki T, Kasuga M, Akanuma Y, Ezaki O, Takaku F (1984) Decreased autophosphorylation of the insulin-receptor kinase in streptozotocin-diabetic rats. J Biol Chem 259: 14208-14216

25. Papachristodoulou DK, Bass PS, Davey PG, Thomas JH (1982) Insulin binding and degradation by kidney cell membrane of streptozotocin-diabetic rats. Horm Metab Res 14: 345-350

26. Rabkin R, Hirayama P, Roth RA, Frank BH (1986) Effect of experimental diabetes on insulin binding by renal basolateral membranes. Kidney Int 30: 348-354
27. Pacold ST, Blackard WG (1979) Central nervous system insulin receptors in normal and diabetic rats. Endocrinology 105: 14521457

28. Havrankova J, Roth J, Brownstein MJ (1979) Concentrations of insulin and insulin receptors in the brain are independent of peripheral insulin levels. J Clin Invest 64: 636-642

29. Gavin JR, Roth J, Neville DM, DeMeyts P, Buell NB (1974) Insulin dependent regulation of insulin receptor concentrations: a direct demonstration in cell culture. Proc Natl Acad Sci USA 71: 84-88

30. Krupp M, Lane MD (1981) On the mechanism of ligand-induced downregulation of insulin receptor level in the liver cell. J Biol Chem 256: 1689-1694

31. Baum M (1987) Insulin stimulates volume absorption in the rabbit proximal convoluted tubule. J Clin Invest 79: 1104-1109

32. Kirchner K (1988) Insulin increases loop segment chloride reabsorption in the euglycemic rat. Am J Physiol 255 (Renal Fluid Electrolyte Physiol. 24): F1206-F1213

33. Eadington DW, Hepburn DA, Swainson CP (1993) Antinatriuretic action of insulin is preserved after angiotensin I converting enzyme inhibition in normal man. Nephrol Dial Transplant 8: 29-35

34. Morris AD, Petrie JR, Anderson J, Connell JMC, Donnelly R (1993) Effects of angiotensin II on insulin sensitivity: a placebocontrolled study. Clin Sci 85: 431-436

35. Townsend RR, DiPette DJ, Lieux TR, Wolfe RR (1993) The role of the renin-angiotensin system in insulin sensitivity in normotensive subjects. Am J Med Sci 305: 67-71

36. Buchanan TA, Thawani H, Kades W, et al. (1993) Angiotensin II increases glucose utilization during acute hyperinsulinemia via a hemodynamic mechanism. J Clin Invest 92: 720-726

37. Widgren BR, Urbanavicius V, Wikstrand J, Attvall S, Persson B (1993) Low-dose angiotensin II increases glucose disposal rate during euglycemic hyperinsulinemia. Am J Hypertens 6: 892-895

38. Ojamaa K, Hedo JA, Roberts CT, Moncada VY, Gorden P (1988) Defects in human insulin receptor gene expression. Mol Endocrinol 2: 242-247

39. Velloso LA, Folli F, Sun XJ, White MF, Saad MAJ, Kahn CR (1996) Cross-talk between the insulin and angiotensin signalling systems. Proc Natl Acad Sci USA 93: 12490-12495

40. Pollare T, Lithell H, Berne C (1989) A comparison of the effects of hydrochlorothiazide and captopril on glucose and lipid metabolism in patients with hypertension. New Engl J Med 321: 868873

41. Prince MJ, Stuart CA, Padia M, Bandi Z, Holland OB (1988) Metabolic effects of hydrochlorothiazide and enalapril during treatment of hypertensive diabetic patients. Arch Intern Med 148: 2363-2368

42. Gans ROB, Bilo HJG, Nauta JJP, Popp-Snijders C, Heini RJ, Donker AJM (1991) The effects of angiotensin-I converting inhibition on insulin action in healthy volunteers. Eur J Clin Invest 21: $527-533$

43. Hartl WH, Jauch K-W, Wolfe RR, Schildberg FW (1990) Effects of kinins on glucose metabolism in vivo. Horm Metab Res 22: 79-84

44. Sasaki S, Bunag RD (1983) Insulin reverses hypertension and hypothalamic depression in streptozotocin diabetic rats. Hypertension 5: 34-40

45. Jyothirmayi GN, Reddi AS (1993) Effect of diltiazem on glomerular heparan sulphate and albuminuria in diabetic rats. Hypertension 21: 795-802

46. Brands MW, Hopkins TE (1996) Poor glycemic control induces hypertension in diabetes mellitus. Hypertension 27: 735-739

47. Hostetter TH, Rennke HG, Brenner BM (1981) Glomerular hemodynamics in experimental diabetes mellitus. Kidney Int 19: 410-415

48. Zatz R, Dunn BR, Meyer TW, Anderson S, Renkke HG, Brenner BM (1986) Prevention of diabetic glomerulopathy by pharmacological amelioration of glomerular capillary hypertension. J Clin Invest 77: 1925-1930

49. Maeda CY, Fernandes TG, Timm HB, Irigoyen MC (1995) Autonomic dysfunction in short term experimental diabetes. Hypertension 26: 1100-1104 